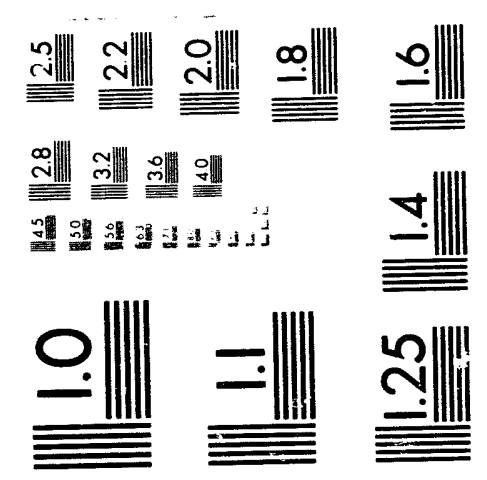



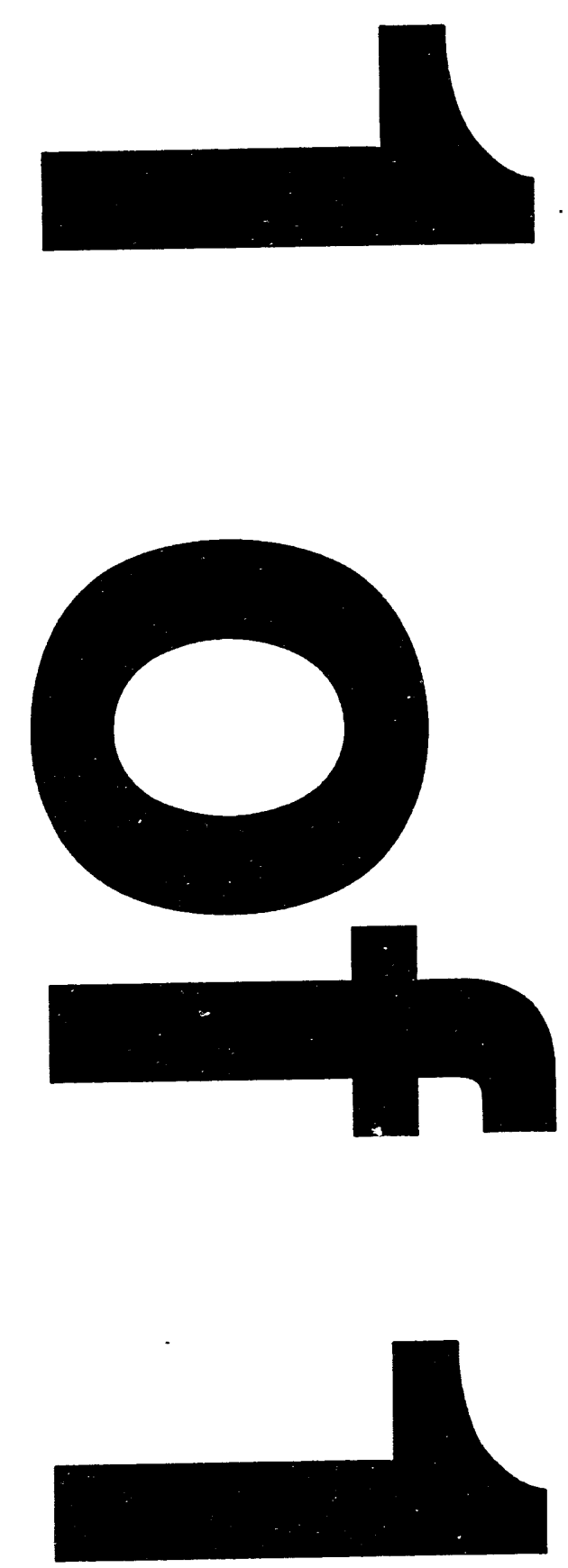
DOEJEIA-0570(92)

Distribution Category UC-950

\section{Uranium Purchases Report 1992}

\section{August 1993}

\section{Energy Information Administration}

Office of Coal, Nuclear, Electric and Alternate Fuels

U.S. Department of Energy

Washington, DC 20585

This report was prepared by the Energy Information Administration, the independent statistical and analytical agency within the Department of Energy. The information contained herein should not be construed as advocating or reflecting any policy position of the Department of Energy or of any other organization. 


\section{Contacts}

The "Uranium Purchases Report 1992" was prepared by the Survey Management Division (SMD), Office of Coal, Nuclear, Electric and Alternate Fuels, Energy Information Administration. Questions of a general nature should be directed to Howard L. Walton, Director
SMD, at 202/254-5500, or to Noel Balthasar, Chief of the Coal and Uranium Data Systems Branch (CUDSB), SMD, at 202/254-5405. Questions of a detailed or technical nature should be addressed to Luther Smith, CUDSB, at 202/254-5565. 


\section{Uranium Purchases Report 1992}

\section{Background}

The Energy Policy Act of 1992 (EPACT 1992), Public Law 102-486 (October 24, 1992), Subtitle B, 42 USC $\$ 2296 b-4$, Sec. 1015, provides that:

... the owner or operator of any civilian nuclear power reactor shall report to the Secretary (of Energy), acting through the Administrator of the Energy Information Administration, for activities of the previous fiscal year-

(1) the country of origin and the seller of any uranium or enriched uranium purchased or imported into the United States either directly or indirectly by such owner or operator; and

(2) the country of origin and the seller of any enrichment services purchased by such owner or operator.

This information is required to be made available to the Congress annually.

\section{Overview}

In the following sections, data reported by domestic nuclear utility companies in their responses to the 1991 and 1992 "Uranium Industry Annual Survey," Form EIA-858, Schedule B "Uranium Marketing Activities," are provided in response to the requirements in the EPACT 1992. Data on utility uranium purchases and imports are shown on Table 1. Utility enrichment feed deliveries and secondary nıarket acquisitions of uranium equivalent of U.S. DOE separative work units are shown on Table 2. Appendix A contains a listing of firms that sold uranium to U.S. utilities during 1992 under new domestic purchase contracts. Appendix B contains a similar listing of firms that sold uranium to U.S. utilities during 1992 under new import purchase contracts. Appendix $C$ contains an explanation of Form EIA-858 survey methodologies with emphasis on the processing of Schedule B data.

\section{Uranium Purchases}

During 1992, the owners and operators of U.S. civilian nuclear electric generating units took delivery of 23.6 million pounds $\mathrm{U}_{3} \mathrm{O}_{B}$ under purchase contract commitments from domestic suppliers, about 3.2 million pounds less (-12 percent) than in 1991 (Table 1). Natural uranium (as $\mathrm{U}_{3} \mathrm{O}_{8}$ and $\left.\mathrm{UF}_{6}\right)^{1}$ accounted for 21.0 million pounds ( 89 percent) and enriched uranium accounted for 2.5 million pounds (11 percent). ${ }^{2}$

Deliveries under new spot contract purchases from domestic suppliers during 1992 accounted for 8.0 million pounds $\mathrm{U}_{3} \mathrm{O}_{8} .{ }^{3}$ During 1992, 40 new spot contracts were signed. The top five origin countries for uranium delivered under spot purchases were Russia, ${ }^{4}$ the United States, Canada, France, and China. Intermediaries accounted for 97 percent of these spot deliveries from domestic suppliers, and producers and others accounted for 3 percent.

Of the 23.6 million pounds delivered by domestic suppliers in 1992, 7.9 million pounds ( 34 percent) were of U.S. origin, 15.1 million pounds (64 percent) were of non-U.S. origin, and 0.5 million pounds ( 2 percent) were of unspecified origin. The top four origin countries for the non-U.S. origin uranium were Russia (25 percent), Canada ( 23 percent), Namibia ( 6 percent), and China (4 percent). U.S. utilities also took delivery of

${ }^{\prime} \mathrm{U}_{3} \mathrm{O}_{8}=$ Uranium concentrate or yellowcake. $\mathrm{UF}_{6}=$ Uranium hexafluoride.

${ }^{2}$ The enriched uranium purchased in 1992 included a small amount of fabricated fuel that was conveyed under an interutility transaction. This material was from a closed U.S. civilian reactor.

${ }^{3}$ As used by the EIA, a spot purchase contract is one in which all deliveries of materials are scheduled to be completed by the end of the first calendar year following the contract-signing year. Deliveries can be made during the contract-signing year, but deliveries aln not scheduled to occur beyond the first calendar year thereafter. A long-term contract is one in which at least one delivery of material is scheduled to occur during the second calendar year after the contract-signing year. Deliveries also can occur during the contract-signing year, during the first calendar year thereafter, or during any subsequent calendar year.

4"Russia" was the origin rountry reported on the Form ElA-858 for 1991 and 1992. No further breakdown into the newly formed, separate Republics, commonly known now as the Commonwealth of Independent States, is available. 
Table 1. Uranium Purchases by Utilities, 1991 and 1992

(Thousand Pounds $\mathrm{U}_{3} \mathrm{O}_{8}$ Equivalent)

\begin{tabular}{|c|c|c|c|}
\hline \multirow[b]{2}{*}{ Category } & & \multicolumn{2}{|c|}{ Quantity } \\
\hline & & 1991 & 1992 \\
\hline \multicolumn{2}{|l|}{ Purchases (Total) ${ }^{a}$} & 40,947 & 35,383 \\
\hline \multicolumn{2}{|c|}{ Purchases from Domestic Suppliers (Total) } & 26,812 & 23,572 \\
\hline \multirow[t]{3}{*}{ By material type: } & Natural $\mathrm{U}_{3} \mathrm{O}_{8}$ & 17,011 & 17,847 \\
\hline & Natural $U_{6}$ & 7,458 & 3,180 \\
\hline & Enriched UF & 2,343 & 2,546 \\
\hline \multirow[t]{12}{*}{ By origin country: ......... } & Australia & 1,374 & W \\
\hline & Canada & 2,943 & 5,347 \\
\hline & China & 1,146 & 920 \\
\hline & France & 0 & W \\
\hline & Gabon & w & 0 \\
\hline & Namibia & 917 & 1,333 \\
\hline & Portugal & W & W \\
\hline & Russia $^{c}$ & 6,824 & 5,831 \\
\hline & South Africa & 0 & 349 \\
\hline & Spain & W & 0 \\
\hline & United Kingdom & W & 0 \\
\hline & United States & 12,443 & 7,934 \\
\hline \multicolumn{2}{|l|}{ Purchased Imports (Total) ${ }^{d}$} & 14,135 & 11,811 \\
\hline \multirow[t]{2}{*}{ By material type: $\ldots \ldots \ldots \ldots$} & Natural $\mathrm{U}_{3} \mathrm{O}_{8}$ & 12,559 & 10,263 \\
\hline & Natural $U F_{6}$ & 1,576 & 1,548 \\
\hline \multirow[t]{8}{*}{ By origin country: $\ldots \ldots \ldots \ldots$} & Australia & 701 & 2,245 \\
\hline & Canada & 11,793 & 7,030 \\
\hline & China & W & W \\
\hline & Gabon & w & W \\
\hline & Germany & W & W \\
\hline & Namibia & 0 & w \\
\hline & Russia & w & 1,123 \\
\hline & South Africa & 0 & w \\
\hline
\end{tabular}

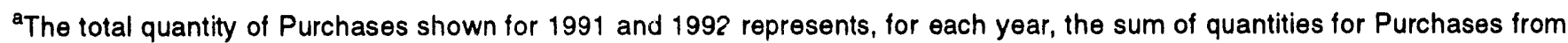
Domestic Suppliers and Purchased Imports.

'DTe total quantity shown for 1991 and 1992 as Purchases from Domestic Suppliers represents, for each year, the sum of the quantities shown by material type and the sum of quantities shown by origin country.

"The name "Russia" was used to report data for 1991 and 1992. No further breakdown into the newly formed, separate Republics, commonly known now as the Commonwealth of Independent States, is available.

d The total quantity shown for 1991 and 1992 as Purchased Imports represents, for each year, the sum of the quantities shown by material type and the sum of quantities shown by origin country. Imported uranium reported as being of U.S. origin is excluded from the imports values shown.

$W=$ Withheld to avoid disclosure of company identifiable data.

Note: Totals may not equal sum of components because of independent rounding.

Source: Energy Information Administration, Form EIA-858, "Uranium Industry Annual Survey." 
Table 2. Utility Enrichment Feed Deliveries, 1991 and 1992

(Thousand Pounds $\mathrm{U}_{3} \mathrm{O}_{8}$ Equivalent)

\begin{tabular}{|c|c|c|c|}
\hline \multirow{2}{*}{\multicolumn{2}{|c|}{ Category }} & \multicolumn{2}{|c|}{ Quantity } \\
\hline & & 1991 & 1992 \\
\hline \multicolumn{2}{|l|}{ Enrichment Feed Deliveries (Total) ${ }^{\mathrm{a}}$} & 37,992 & 32,045 \\
\hline \multicolumn{2}{|l|}{ To U.S. Department of Energy (Total) ${ }^{b}$} & 33,852 & 27,622 \\
\hline \multicolumn{2}{|l|}{ U.S. Origin Uranlum . } & 11,711 & 9,077 \\
\hline \multicolumn{2}{|l|}{ Non-U.S. Origin Uranium } & 22,141 & 18,545 \\
\hline \multirow[t]{10}{*}{ By origin country: $\ldots \ldots \ldots$} & Australia & 2,641 & 1,784 \\
\hline & Canada & 11,327 & 8,984 \\
\hline & China & W & W \\
\hline & France & W & W \\
\hline & Gabon & W & W \\
\hline & Namibia & W & W \\
\hline & Portugal & 0 & W \\
\hline & Russia ${ }^{c}$ & 3,176 & 5,146 \\
\hline & South Africa & W & 662 \\
\hline & United Kingdom & W & W \\
\hline \multicolumn{2}{|l|}{ To Non-U.S. Enrichers (Total) ${ }^{d}$} & 4,140 & 4,423 \\
\hline \multicolumn{2}{|l|}{ U.S. Origin Uranium (Total) } & 2,120 & 1,048 \\
\hline \multirow[t]{3}{*}{ Enrichment suppliers } & Eurodif .......... & W & W \\
\hline & Urenco.......... & W & W \\
\hline & Tenex .......... & W & W \\
\hline \multicolumn{2}{|l|}{ Non-U.S. Origin Uranium (Total) . } & 2,020 & 3,375 \\
\hline \multirow[t]{3}{*}{ Enrichment suppliers: $\ldots \ldots$} & Eurodif .......... & W & W \\
\hline & Urenco........... & W & W \\
\hline & Tenex .......... & W & W \\
\hline \multicolumn{4}{|l|}{ U.S. DOE Separative Work Units (SWU) } \\
\hline \multicolumn{4}{|l|}{ Purchased or Received in Exchange in the } \\
\hline \multicolumn{2}{|l|}{ Secondary Market } & 1,562 & 1,031 \\
\hline
\end{tabular}

aThe total quantity of Utility Enrichment Feed Deliveries shown for 1991 and 1992 represents, for each year, the surn of materials shipped for enrichment to U.S. Department of Energy (DOE) and to Non-U.S. Enrichers.

'The total quantity for 1991 and 1992 shipped to U.S. Department of Energy represents, for each year, the sum of U.S. Origin Uranium and Non-U.S. Origin Uranium.

"The name "Russia" was used to report data for 1991 and 1992 . No further breakdown into the newly formed, separate Republics, commonly known now as the Commonwealth of Independent States, is available.

The total quantity for 1991 and 1992 shipped to Non-U.S. Enrichers represents, for each year, the sum of U.S. Origin Uranium and Non-U.S. Origin Uranium.

$W=$ Withheld to avoid disclosure of company identifiable data.

Note: Totals may not equal sum of components because of independent rounding.

Source: Energy Information Administration, Form ElA-858, "Uranium Industry Annual Survey." 
11.8 million pounds $\mathrm{U}_{3} \mathrm{O}_{8}$ in 1992 under direct-import, purchase contract commitments. Listed in descending rank urder, the top three origin countries for uranium imports were Canada (60 percent), Australia (19 percent), and (Russia 10 percent). China, Gabon, Cermany, Namibia, and South Africa accounted for the remaining utility imports.

Of the 11.8 million pounds imported in 1992, 2.2 million pounds were delivered under 15 new spot purchase import contracts signed during the year. Australia, Russia, China, and South Africa were the origin countries for 80 percent of the uranium delivered under spot import purchases. Intermediaries accounted for 59 percent of the import spot deliveries and foreign producers accounted for 41 percent.

\section{Uranium Enrichment}

In 1992, three new long-term enrichment service contracts were signed by U.S. utilities, one each with Eurodif, Tenex, and Urenco. ${ }^{5}$ These contracts largely involve deliveries beginning in 1996. The U.S. Department of Energy reported that it entered into no new long-term contracts for enrichment services in 1992. Several utilities reported modifying their existing U.S. DOE enrichment contracts during 1992 to change quantities, prices, and/or deliveries or to elect and finalize future enrichment options remaining under those contracts.

Actual deliveries of uranium feed to enrichment plants each year by U.S. utilities are shown on Table 2. In
1992, utility enrichment feed deliveries totaled 32.0 million pounds $\mathrm{U}_{3} \mathrm{O}_{8}$ shipped to both domestic and foreign enrichment suppliers, nearly 16 percent below the 1991 level. Deliveries to the U.S. Department of Energy were 27.6 million pounds (86 percent of total deliveries), consisting of 9.1 million pounds (33 percent) of U.S. origin and 18.5 million pounds ( 67 percent) of non-U.S. origin uranium. For non-U.S. origin uranium, the top four origin countries in descending rank order were Canada (48 percent), Russia ( 28 percent), Australia (10), and South Africa (4). The remaining 11 percent of the non-U.S. origin uranium delivered was from China, France, Gabon, Namibia, Portugal, and the United Kingdom.

Utility enrichment feed deliveries to non-U.S. enrichers in 1992 totaled 4.4 million pounds $\mathrm{U}_{3} \mathrm{O}_{8}$ (14 percent of total deliveries). This represents an increase of 7 percent above like shipments in 1991. Of the 1992 deliveries, 1.0 million pounds ( 24 percent) were of U.S. origin and 3.4 million pounds ( 76 percent) were of non-U.S. origin uranium. For U.S. and non-U.S. origin feed materials shipped for foreign enrichment, Eurodif, Urenco, and Tenex provided enrichment services.

In addition to meeting their needs for enriched uranium through primary enrichment service contracts, utilities also obtained enriched uranium in 1992 through purchases or exchanges in the secondary market. These transactions contained 1.0 million pounds $\mathrm{U}_{3} \mathrm{O}_{8}$ equivalent of U.S. DOE separative work units. This quantity was 34 percent less than like secondary market transactions in 1991.

\footnotetext{
'Eu rodif, a consortium of Cogéma, 37 percent; Sofidif, 25 percent (Cogéma 60 percent and OIAETI (Iran) 40 percent); Synatom (Belgium) and Enusa (Spain), 11 percent each; and ENEA and AGIP (both Italy), 8 percent each, operates the Georges Besse gaseous diffusion plant at the Tricastin site in France. Cogéma handles sales and marketing of Eurodif products and services, excluding sales to Eurodif partners. Tenex (Techsnabexport) utilizes four gas centrifuge technology plants at Ekaterinburg, Angarsk, Krasnoyarsk, and Tomsk in Russia. The four plants are owned by The Ministry of Atomic Energy of the Russian Federation (Minatom). Urenco is a European consortium created by treaty between Germany, the Netherlands, and the United Kingdom. Urenco has three gas centrifuge plants, each largely owned by the country wherein it is located: Almelo, the Netherlands, 49 percent each by UCN (Dutch Government) and Uranit (PREAG, RWE, Hoechst, and NUKEM (Germany)), and 2 percent by BNFL; Gronau, Germany, 96 percent Uranit and 2 percent each by UCN and BNFL; and Capenhurst, United Kingdom, 96 percent BNFL and 2 percent each by UCN and Uranit.
} 


\section{Appendix A}

\section{Sellers of Uranium to U.S. Utilities Under New Domestic Uranium Purchase Contracts, 1992}

The following listing provides the names of companies that were reported by domestic utilities as the sellers (i.e., the other party) of uranium under new purchase contracts signed during 1992 for deliveries from domestic suppliers. In 1992, there were 53 new purchase contracts signed, consisting of 40 spot and 13 long-term contracts. The companies were reported on Schedule B, "Uranium Marketing Activities," on the 1992 Form ElA858, "Uranium Industry Annual Survey."

Seller (Other party named in purchase contract)

Allied-Signal, Inc.

Everest Exploration, Inc.

Nuclear Fuels Corporation of South Africa

NUEXCO Trading Corporation

NUKEM, inc.

Power Resources, Inc.

UG, U.S.A., Inc. 


\section{Appendix B}

\section{Sellers of Uranium to U.S. Utilities Under New Imported Uranium Purchase Contracts, 1992}

The following listing provides the names of companies that were reported by domestic utilities as the sellers (i.e., the other party) of uranium under new import purchase contracts signed during 1992 for deliveries of foreign-origin materials. In 1992, there were 26 new imports purchase contracts signed, consisting of 15 spot and 11 long-term contracts. The companies were reported on Schedule B, "Uranium Marketing Activities," on the 1992 Form EIA-858, "Uranium Industry Annual Survey."

\section{Seller (Other party named in purchase contract)}

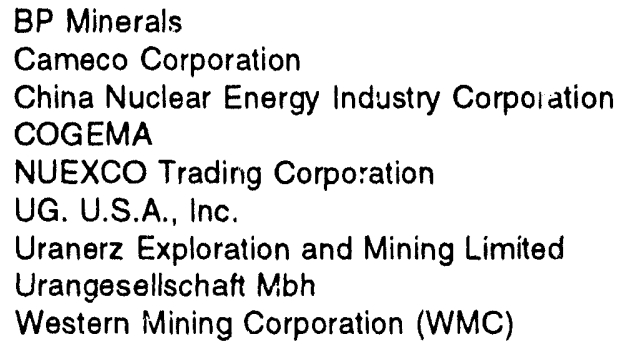




\section{Appendix C}

\section{Survey Methodology}

\section{Survey Design}

The Energy Information Administration (EIA) conducted the ninth annual "Uranium Industry Annual Survey," Form EIA-858, to collect information from all companies known or believed to have been involved in the U.S. uranium industry during 1992. Included in this survey are domestic utilities that own and/or operate nuclear power reactors. Tite 1992 survey form was mailed to respondents in December 1992.

Respondents to the "Uranium Industry Annual Survey" were asked to provide data current to the end of 1992 about their Uranium Raw Materials Activities (Schedule A), Uranium Marketing Activities (Schedule B), and Uranium Industry Financial Status (Schedule C).

In particular, Schedule B covers: uranium transaction parameters including name of the other party; type of transaction; uranium materials covered; origin for the uranium materials and conversion and enrichment services, and delivery destination; importation and exportation; contract pricing mechanism; contract $\mathrm{sp}$ tions; litigation status; schedule of uranium deliveries with corresponding prices; uranium inventories; materials shipped for enrichment and secondary market acquisitions of separative work units (SWU); projected enrichment feed deliveries; and unfilled market requirements. Quantities of uranium reported are as equivalent $\mathrm{U}_{3} \mathrm{O}_{3}$ to the nearest thousand pounds.

The data collected on Form EIA-858 are subject to several sources of error. These sources are: (1) coverage (the respondent frame might not be complete or, on the other hand, there might be double counting); (2) nonresponse (all units that are surveyed might not respond or might not provide all the information requested); (3) respondents (respondents might commit errors in reporting the data); (4) processing (the data collection agency might omit or incorrectly transcribe a submission); (5) concept (the data collection elements might not measure the items they were intended to measure); and (6) adjustments (errors might be made in estimating values for missing data).

Because the "Uranium Industry Annual Survey" is a universe survey rather than a sample survey, sampling errors do not affect the data provided in this report. ${ }^{6}$ Although it is not possible to present estimates of nonsampling error, precautionary steps were taken at each stage of the survey design and operation to minimize the possible occurrence of these errors. These steps are described below, and the errors they were designed to minimize are named (in parenthesis).

\section{Survey Universe and Frame (Coverage Errors)}

The survey universe includes all nuclear utilities involved in the U.S. uranium industry. The criteria for responding to Schedule B are: firms that during 1992 (1) held existing contracts covering the Sale, Purchase, Exchange, Loan, or Loan Repayment of uranium or entered in to similar new contracts; (2) held inventories of uranium in any form excluding reactor-inserted, fabricated fuel; (3) maintained a forward-coverage, uranium-inventory policy (utilities only); (4) had uranium available for sale; and/or (5) made actual deliveries of uranium feed materials to any enrichment supplier.

The respondent list used for the Form EIA-858 survey was developed from a frame of all establishments known to meet the selection criteria. The frame of potential respondents was compiled from previous surveys and from information in the public domain. As it specifically relates to Schedule B, the frame was intended to cover the following: all utilities owning nuclear-fueled generating stations, fuel converters and fabricators, and utilities with whole or partial ownership in operating or planned uranium-fueled power plants.

\footnotetext{
${ }^{6}$ Sampling error is a measure of the variation that occurs by chance because a sample rather than a complete enumeration of units is surveyed.
} 


\section{Survey Procedures (Nonresponse)}

The survey forms were sent via first class mail to ensure their receipt only by the proper res-ondent organization. If the U.S. Postal Service was unable to deliver the survey form, the corrected address was obtained where possible. All known nuclear utilities currently conducting business in the U.S. uranium industry were contacted during this survey.

The Form EIA-858 is a self-administered questionnaire requesting data about many areas of company operations and finances. The scope of the questions is necessarily broad, and self-reporting of companyspecific data is required.

Cooperation from industry on the 1992 survey was, as in previous years, excellent. A large number of respondents replied to the form within the specified deadlines. Those that had not responded by the due dates were telephoned to encourage submission of the forms, and those calls resulted in the submission of most of the remaining forms. In addition, a followup letter was mailed to nonrespondents requesting compliance with the survey. Subsequently, telephone calls were made to obtain forms not yet submitted. In some instances, company data were modified/collected through telephone conversations made to clarify items reported/omitted on their submissions.

To reduce the reporting burden on the respondents, data for contracts and selected other data elements from the prior year's survey form were preprinted on each respondent's 1992 questionnaire.

\section{Data Editing, Analysis, and Processing (Respondent and Processing Errors)}

The survey forms were logged in and reviewed by agency personnel prior to data entry into the Uranium Industry Annual System, an automated data base containing all current and historical data from each company's submission. The data base is maintained on the EIA computer facility in Washington, DC. After entry into the data base, a copy of each Schedule B was distributed to the Survey Management Division analyst for review and approval. The submissions were checked for internal consistency, and the reported data were compared with previous collections of similar data. After reviewing the submissions, the analyst consulted with the reporting company, as needed, to resolve data problems and to confirm any corrections of the data. Data areas that were reviewed and the corrections that were made differed from company to company. Most represented differing interpretations of the data item definitions. No data in the data base were changed without first consulting with the reporting company. Computer edits were also used to identify keypunch errors, out-of-range values, and unlikely data combinations. These edits also were either corrected to represent the data reported on the submissions or werc changed only after confirming the corrected values by telephone conversations with company representatives. Data coding and entry errors were eliininated by proofing data after entry. All changes to reported data were documented.

\section{Response Rates}

Schedule B of Form EIA-858 was mailed to 145 firms and to the Office of Business Operations, Deputy Assistant Secretary for Uranium Enrichment (NE-32), U.S. Department of Energy. All of the schedules that were mailed to nuclear utilities and to NE-32 were returned (100 percent response) with information as requested on the form. Of course, not all Schedule B data items were applicable to each responding utility or to NE-32.

\section{Missing Data}

Omissions of data identified during the prescreening and editing of the data fell into two categories: data that were withheld because of contractual constraints or $b_{c}$ :-use a particular contract was under litigation. Respondents were contacted regarding omissions to verify that the data could not be reported. Only confirmed company-reported data are contained in the data base and included in this report.

\section{Nondisclosure of Data}

To protect the confidentiality of individual respondents' data, a policy was implemented to ensure that the reporting of survey data in this report would not associate those data with a particular company. This policy is in compliance with EIA Standard No. 88-05-06, "Nondisclosure of Company Identifiable Data in Aggregate Cells." In tables where the nonzero value of a cell is composed of data from fewer than three companies or if a single company dominates a table-cell value so that the reporting of the value would lead to identification of a company's data, then the EIA classifies the cell value as "sensitive," and the cell value is withheld ("W") from the report. Within a table with a sensitive cell value, selected values in other cells of the table are also withheld, as necessary, so that the sensitive cell value cannot be computed using the values in published cells.

$$
\text { *U.S. G.P.0.: 1993-343-169;80174 }
$$



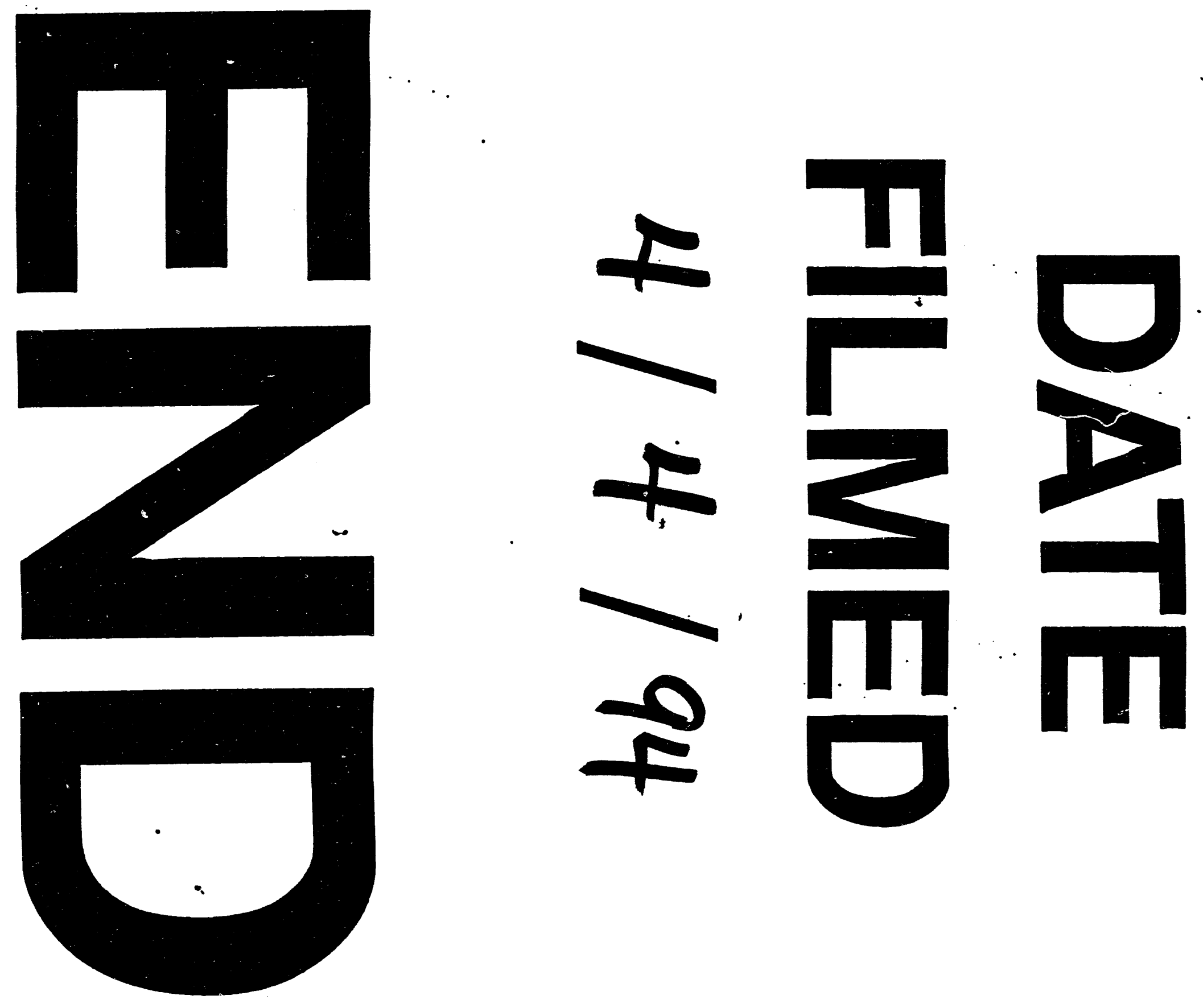
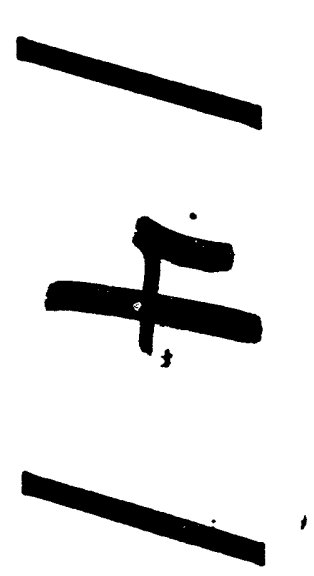

₹ 